\title{
Pembelajaran Geometri Menggunakan Aplikasi Geogebra Versi Android
}

\author{
Fitriani $^{{ }^{*}}$, Sulasri Suddin ${ }^{1}$, Abdullahi $^{2}$ \\ ${ }^{1}$ Pendidikan Matematika, Universitas Timor, Km.9, Kefamenanu, Indonesia, 85613 \\ ${ }^{2}$ M.Ts. Nurul Falah, Jalan Imam Bonjol, Kefamenanu, Indonesia, 85611 \\ *Email Korespondensi: bhrfitriani@gmail.com
}

\begin{abstract}
Abstrak
Geogebra merupakan salah satu aplikasi yang dapat digunakan untuk mempelajarai topik geometri pada matapelajaran matematika. Aplikasi ini sudah tersedia dalam versi android yang dapat dijalankan melalui smartphone. Penggunaan smartphone khususnya di kalangan pelajar di Indonesia yang begitu besar menjadi landasan tim pengabdi memberikan pelatihan penggunaan Geogebra versi android. Pelatihan ini bertujuan untuk memanfaatkan penggunaan smartphone melalui aplikasi Geogebra versi android untuk mempelajari konsep matematika khususnya topik geometri. Pelatihan dibagi menjadi tiga sesi yaitu sesi pengenalan fiturfitur Geogebra versi android, sesi pemaparan materi-materi geometri beserta contoh soal yang penyelesaiannya menggunakan Geogebra versi android dan sesi terakhir pemberian soal-soal latihan. Tim pengabdi juga memberikan angket pengetahuan awal mengenai geogebra dan tes kemampuan awal. Di akhir pelatihan diberikan pula tes akhir yang juga berisi pendapat siswa mengenai penggunaan geogebra versi andoid. Hasil kegiatan pengabdian menujukkan bahwa terdapat peningkatan skor siswa antara tes awal dan tes akhir serta waktu pengerjaan yang lebih cepat dikarenakan penggunaan sogtware Geogebra versi android. Respon dan pendapat siswa mengenai penggunaan aplikasi ini juga positif dan sangat antusias.
\end{abstract}

Kata kunci: Geometri; geogebra; aplikasi android

\begin{abstract}
Geogebra is an application which can be used to learn about topic in geometry, mathematics lesson. This application available in android version which can be run through smartphone. The enormous use of smartphone in Indonesia forms the basis of the service team to provide Geogebra android version `s training. The training consist of three sessions, first session is feature introduction og geogebra android version, second session is sharing knowledge about Geogebra usage and last session is to answers exercise questions about topic ini Geometry. Service team also give an initial knowledge guestionnaire and an initial proficiency test. At the last training, service team give a last test accompanied by student opinions regarding the use of geogebra android version. Found improvement of student's score beetwen initial test and last test and processing time is faster.Student response about this application is very good and enthusiastic.
\end{abstract}

Keywords: Geometry; geogebra; android applications

Format Sitasi: Fitriani, Suddin, S., Abdullahi. (2020). Pembelajaran Geometri Menggunakan Aplikasi Geogebra Versi Android. Jurnal Solma, 09(2), 270-277. Doi: http://dx.doi.org/10.22236/solma.v9i2.5498

Diterima: 29 Agustus 2020 | Revisi: 05 September 2020 | Dipublikasikan: 30 Oktober 2020

(C) 2020 Oleh authors. Lisensi Jurnal Solma, LPPM-Uhamka, Jakarta. Artikel ini bersifat open access yang didistribusikan di bawah syarat dan ketentuan Creative Commons Attribution (CC BY) license. (http://creativecommons.org/licenses/by/4.0/).

\section{PENDAHULUAN}

Saat ini, smartphone menjadi kebutuhan primer bagi sebagian besar orang di seluruh dunia. Beragamnya jenis dan varian smartphone serta aplikasi yang ditawarkan oleh produsen menambah daya minat masyarakat terhadap pemilikan dan penggunaannya. 
Tidak hanya kalangan orang dewasa, penggunaan smartphone juga sangat digemari di kalangan remaja.

Di kalangan remaja, penggunaan smartphone didominasi oleh sosial media dan game (Muflih et al., 2017), baik di rumah maupun di sekolah, padahal smartphone android sebenarnya sudah menyediakan banyak aplikasi edukasi pada playstore. Oleh karena itu, perlu adanya bimbingan terhadap para remaja usia sekolah untuk memaksimalkan penggunaan smartphone sebagai sarana edukasi daripada hanya bersosial media atau bermain game. Penggunaan smartphone sebagai media edukasi menambah ragam media pembelajaran dan dapat diaplikasikan dengan mudah. Hal ini juga dapat dikategorikan sebagai penerapan teknologi dalam pembelajaran

Dalam pengajaran, guru sudah menggunakan beberapa media pembelajaran. Namun media pembelajaran tersebut masih berupa gambar atau benda replika yang telah jadi misalnya seperti persegi dan segitiga yang terbuat dari kayu. Replika-replika tersebut bentuk dan ukurannya tidak fleksibel dan membutuhkan ruang peyimpanan yang besar (Yunita, 2020). Media pembelajaran seperti ini belum memanfaatkan teknologi komputer yang sudah sangat berkembang. Aplikasi geogebra inilah yang dipandang sebagai suatu alternatif media pembelajaran dengan memanfaatkan teknologi yang juga telah tersedia dalam versi android sehingga dapat digunakan melalalui smartphone.

Topik geometri merupakan salah satu topik yang dianggap sulit untuk diajarkan. Hal ini dikarenakan konsep-konsep yang terdapat didalamnya bersifat sangat abstrak (Kusuma \& Eka, 2015). Dalam memahami konsep, para siswa harus dapat membayangkan hal yang sifatnya abstrak menjadi suatu hak yang sifatnya konkret. Untuk dapat mewujudkan hal tersebut diperlukan suatu alat atau media yang sebaiknya erat dengan kehidupan sehari-hari para siswa. Tim pengabdi menemukan ide untuk menggunakan salah satu aplikasi matematika yang diinterpretasikan dalam versi android yang terdapat pada smart phone, mengingat saat ini para siswa setiap harinya bergantung pada sebuah smartphone.

Tujuan diadakannya kegiatan pengabdian ini yaitu diharapkan dapat memberikan alternatif penggunaan media pembelajaran yang akrab dengan keseharian para siswa yaitu smartphone. Aplikasi software yang digunakan juga memiliki kapasitas penyimpanan yang relatif kecil dan dapat dioperasikan tanpa akses internet (offline). Kegiatan pengabdian ini juga merupakan salah satu bentuk implementasi pelaksanaan tri dharma perguruan tinggi di bidang pengabdian, mengingat tim pengabdi merupakan dosen pada Fakultas Ilmu Pendidikan Universitas Timor. Selain itu kegiatan pengabdian ini menjadi kegiatan kerjasama antara Universitas Timor dengan sekolah mitra yaitu M.Ts. Nurul Falah yang diharapkan berlangsung konsisten dan berkesinambungan.

\section{MASALAH}

Berdasarkan hasil diskusi dan wawancara dengan guru mata pelajaran matematika di M.Ts. Nurul Falah Kefamenanu, Kabupaten Timor Tengah Utara, Nusa Tenggara Timur, dalam proses belajar mengajar, khususnya topik geometri beberapa permasalahan yang dihadapi oleh guru adalah:

1. Guru-guru hanya menerapkan pembelajaran langsung, padahal materi matematika khususnya topik Geometri membahas mengenai objek yang abstrak. 
2. Guru-guru belum memiliki dan mencoba menggunkan software matematika seperti Geogebra sebagai alat bantu dalam proses belajar mengajar

3. Siswa sangat tergantung dan sering menghabiskan waktu menggunaan smartphone (gadget)

4. Kurangnya minat siswa dalam belajar matematika.

5. Guru belum meyadari pentingnya variasi dalam proses belajar mengajar sehingga mampu membangkitkan keingintahuan siswa dalam proses belajar mengajar.

6. Kurangnya motivasi guru-guru matematika dalam mengembangkan perangkat pembelajaran

Merujuk pada permasalahan point satu dan tiga, tim pengabdi yang telah berkoordinasi dengan pihak mitra yaitu M.Ts. Nurul Falah Kefamenanu mengadakan pelatihan mengenai pembelajaran geometri menggunakan suatu software ringan yang dapat diaplikasikan menggunakan smartphone. Aplikasi Geogebra dipilih dikarenakan pengunaannya lebih sederhana dengan kapasitas penyimpanan yang kecil. Aplikasi ini pula telah tersedia dalam versi android yang dapat diperoleh pada playstore smartphone android. Selain itu aplikasi ini juga dapat dijalanakan secara offline (tanpa menggunakan paket data).

\section{METODE PELAKSANAAN}

Adapun metode yang digunakan untuk menyelesaikan masalah di atas yaitu:

1. Konsultasi, sebelum tim pengabdi menawarkan solusi dari permasalahan, tim pengabdi melakukan wawancara secara khusus guru mata pelajaran dan berkonsultasi mengenai ide/gagasan penggunaan software matematika yaitu Geogebra versi android yang terkait dengan permasalahan point ke tiga yaitu ketergantungan siswa terhadap penggunaan smartphone.

2. Pelatihan

Guru mata pelajaran bersama-sama tim pengabdi melakukan pelatihan mengenai cara penggunaan software Geogebra versi android. Pelatihan ini diikuti oleh siswa-siswi M.Ts. Nurul Falah yang sudah pernah mendapatkan teori dan konsep geometri. Terlebih dahulu diberikan pengenalan fitur-fitur yang ada pada Geogebra versi android. Selanjutnya dibahas konsep-konsep geometri seperti titik, garis, menentukan persamaan garis sejajar atau tegak lurus dan melalui suatu titik, luas bangun-bangun datar, konsep sudut dan kemiringan, serta transformasi berupa geseran, pencerminan rotasi dan dilatasi. Pelaksanaan kegiatan puncak ini dilaksanakan pada tanggal 21 Maret 2020.

3. Advokasi

Selain pelatihan penggunaan software Geogebra, tim pengabdi juga berkoordinasi dengan guru mata pelajaran matematika untuk melakukan pendampingan kepada para siswa yang kesulitan dan ingin mempelajari fitur-fitur yang terdapat pada software Geogebra versi android. Langkah awal dibentuk small grup discussion yang nantinya akan memudahkan tim pengabdi melakukan pendampingan dan mengontrol siswa yang perlu mendapatkan bimbingan khusus.

Pengumpulan data dilakukan dalam lima tahap yaitu observasi awal, pemberian angket pengetahuan awal, pemberian tes awal, pemberian tes akhir dan wawancara dengan siswa. 
Selain itu terdapat pula rekaman video dan audio dari setiap tahapan. Tahap observasi awal memberikan tim pengabdi gambaran mengenai masalah yang terjadi di sekolah mitra. Angket pengetahuan awal dimaksudkan untuk mengetahui seberapa jauh siswa mengenal aplikasi Geogebra dan kesiapan dalam menerima materi. Sebelum memulai pelatihan kepada siswa, terlebih dahulu diberikan tes awal yang berisi soal-soal dengan topik geometri yang diselesaiakan secara manual (dengan rumus dan perhitungan aljabar biasa). Setelah pemberian materi, diberikan tes akhir yang diselesaikan dengan bantuan software Geogebra. Pada lembar tes akhir diberikan kolom komentar dan pendapat siswa mengenai penggunaan software ini. Wawancara dilakukan kepada guru dan siswa. Wawancara dengan guru dilakukan pada saat observasi awal, sedangkan wawancara dengan siswa dilakukan setelah pelatihan berakhir.

Teknik analisis data yang digunakan yaitu reduksi data dan penyajian data. Teknik reduksi yang dilakukan dimulai dari data masalah masalah yang terjadi dipilih masalah yang menurut tim pengabdi paling urgent untuk diselesaikan. Hasil wawancara siswa juga direduksi dengan cara mengelompokkan pendapat para siswa yang memiliki kemiripan terutama dari segi konten atau isi pendapat tersebut. Penyajian data dilakukan terhadap datadata hasil angket pengetahuan awal, tes awal dan tes akhir.

Pelaksanaan pengabdian ini dipusatkan pada M.Ts Nurul Falah yang jaraknya sepuluh km dari kampus Universitas Timor. Sasaran utama pengabdian adalah siswa SMP/M.Ts yang sedang atau telah mempelajari topik-topik geometri pada mata pelajaran matematika. Durasi waktu pengabdian mulai dari persiapan sampai dengan pelatihan selama dua minggu. Namun sebagai tindak lanjut, setelah kegiatan puncak pada tanggal 21 Maret 2020, tim pengabdian bersama mitra masih melakukan kerjasama dan pembimbingan berbentuk small group discussion bersama siswa ataupun focus group discussion dengan para guru mata pelajaran matematika.

\section{HASIL DAN PEMBAHASAN}

Salah satu topik pembahasan pada matpelajaran matematika yang dianggap sulit yaitu topik geometri (Bernard \& Senjayawati, 2019). Hal ini dikarenakan geometri sangat erat dengan sifat-sifat yang abstrak. Siswa perlu membayangkan atau melihat benda serta interpretasi gambar yang dimaksud. Oleh karena itu, tim pengabdian ini memiliki inisiatif untuk menggunakan software matematika dalam membantu siswa memahami konsep dalam geometri. Tim pengabdi memilih software Geogebra karena software ini salah satu software dengan kapasitas ringan dan mudah dipahami. Penggunaan software inipun sangat sederhana. Tim pengabdian juga mahir menggunakan dan mengaplikasikan software geogebra dalam pembelajaran di kelas.

Kegiatan pengabdian ini mendapat respon positif dari guru mata pelajaran matematika dan peserta pelatihan. Selama pengabdian terdapat beberapa temuan yaitu, keefektifan dan kebermanfaatan dari penggunaan aplikasi geogebra. Siswa peserta pelatihan mengikuti rangkaian kegiatan dengan tertib. Adapaun data yang diperoleh dari hasil pengabdian yaitu data berupa pengetahuan awal mengenai aplikasi geogebra, tes kemampuan awal dan test akhir. Selain itu terdapat pula data wawancara terhadap guru matapelajaran dan siswa peserta pelatihan. Angket pengetahuan awal berisi pertanyaan mengenai seberapa jauh para 
siswa peserta pelatihan mengenal software Geogebra, 80\% peserta pelatihan belum mengenal aplikasi geogebra, 20\% sisanya sudah mengenal aplikasi geogebra namun masih dalam aplikasi pada komputer. Data berikut menujukkan adanya peningkatan skor tes kemampuan awal dan tes akhir dari beberapa peserta pelatihan.

Tabel 1. Skor tes awal dan tes akhir peserta pelatihan

\begin{tabular}{lcc}
\hline \multicolumn{1}{c}{ Nama } & $\begin{array}{c}\text { Skor Tes } \\
\text { Awal }\end{array}$ & $\begin{array}{c}\text { Skor Tes } \\
\text { Akhir }\end{array}$ \\
\hline Mutiara Tridifa Sakina Tahrin & 14 & 50 \\
Fauziah & 7 & 64 \\
Nur Fauziah Ain & 7 & 57 \\
Syahrani Aulia Norsajida & 14 & 64 \\
Nayla Nadira Khairiyah & 14 & 57 \\
Nabila Khalif Fatima & 7 & 36 \\
Moh. Fhatoni & 10 & 50 \\
Agung Prasetyo & 10 & 71 \\
Kusnia Azzara & 14 & 64 \\
Zaima Adzani Dzuhur Mae & 14 & 64 \\
Robiatun Hadawiyah & 7 & 71 \\
Putri Amelia Zalsabila & 14 & 64 \\
Muh. Ikhram & 21 & 57 \\
Muhammad Irsan & 14 & 79 \\
Muhammad Ishaqul Muttaqin & 10 & 64 \\
Bagus Setiawan & 10 & 79 \\
Dwi Zajilah Mutmainah & 14 & 36 \\
Antika Ratri & 7 & 50 \\
Wahyudi M & 21 & 71 \\
\hline
\end{tabular}

Diketahui bahwa terdapat peningkatan skor tes awal dan tes akhir dari para peserta pelatihan (Tabel 1). Pada saat mengerjakan tes awal, peserta masih menggunakan perhitungan biasa dan pada saat mengerjakan tes akhir, peserta sudah menggunakan aplikasi Geogebra di smartphone masing-masing. Waktu yang diperlukan dalam mengerjakan soal tes akhir juga lebih cepat karena menggunakan aplikasi geogebra (Fitriani et al., 2019). Berikut rangkuman hasil wawancara dengan setelah pemberian pelatihan penggunaan aplikasi geogebra :

1. Penjelasan pada saat pelatihan sangat mudah dimengerti

2. Penggunaan Geogebra versi android sangat mudah

3. Mengerjakan sola-soal matematika menjadi lebih mudah dan cepat dengan menggunakan geogebra.

4. Pemaparan materi sangat menarik dan mudah dipahami 

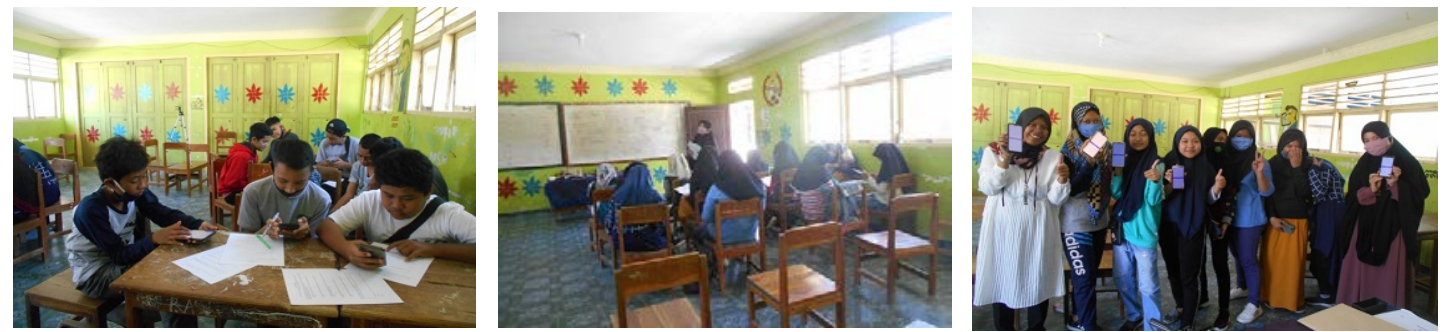

Gambar 1. Mengerjakan tes dan pemaparan materi

Geogebra, dalam perkembangannya sudah tersedia dalam versi android. Hal ini menambah keragaman dari media belajar yang mudah diaplikasikan dan sangat dekat dengan kehidupan sehari-hari para siswa. Dalam pelatihan, siswa lebih mudah memahami konsep misalnya sifat kesejajaran dari dua garis lurus yaitu memiliki gradien/kemiringan garis yang sama serta syarat dua garis tegak lurus apabila perkalian kedua garisnya menghasilkan -1 (Chronika et al., 2019). Hal ini sejalan dengan hasil penelitian yang menyatakan bahwa dengan media geogebra dapat meningkatkan pemahaman konsep siswa (Annajmi, 2016), (Ningsih et al., 2019).

Dalam pelatihan diberikan pula soal-soal nonrutin dan soal-soal cerita yang terkait dengan topik geometri. Hal ini juga menunjukkan bahwa geogebra dapat dipandang sebagai salah satu media yang dapat digunakan dalam meningkatkan kemampuan pemecahan masalah matematis (Ramadhani, 2016), (Sari et al., 2019). Para siswa dapat dengan mudah menyelesaikan soal tanpa harus melakukan algoritma hitungan lagi.

Keuntungan yang juga diperoleh dari penggunaan aplikasi Geogebra ini yaitu guru dapat dengan mudah memeriksa jawaban tugas-tugas khususnya topik geometri. Siswa juga dapat mnegecek apakah jawaban yang dikerjakan secara manual sudah benar atau belum (Qurohman et al., 2018). Dalam rangkaian kegiatan pelatihan ini, tim pengabdi juga memberikan beberapa contoh lembar kerja yang sudah menggunakan aplikasi Geogebra khususnya dalam hal interpretasi grafis. Guru dapat dengan mudah mendesaian gambar bangun datar, garis, sinar, ruas gris, vektor dan bentuk-bentuk transformasi linear seperti rotasi, geseran refleksi dan lain sebagainya (Herlina et al., 2019). Hal ini menunjukkan bahwa aplikasi Geogebra ini juga dapar merangsang kreatifitas guru dalam membuat lembar kerja.
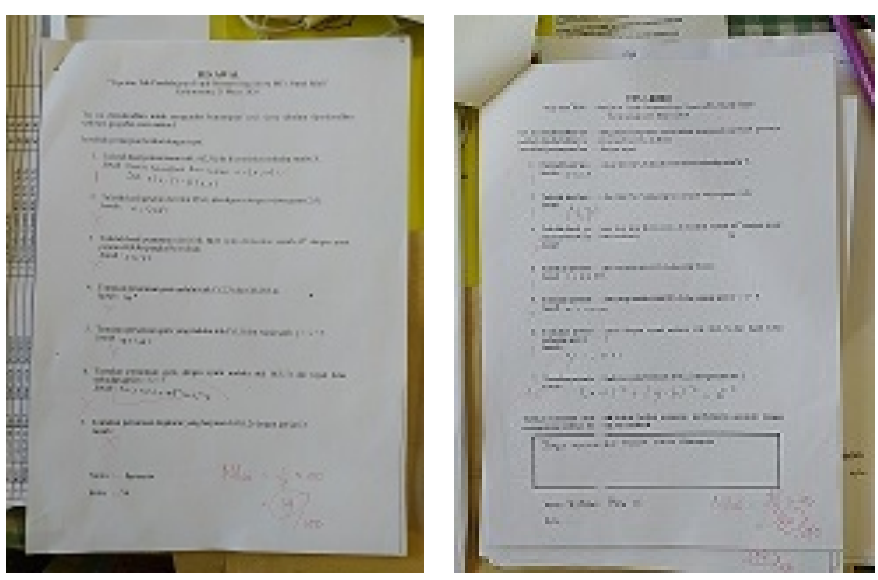

Gambar 2. Tes awal dan tes akhir salah satu peserta pelatihan 
Berbagai penelitian telah menunjukkan beberapa kelebihan dari penggunaan software Geogebra ini. Geogebra sangat cocok diterapkan dalam mengajarkan materi geometri di tingkat SMP atau sederajat (Agung, 2016). Selain itu dengan menggunakan software ini, berbagai kemampuan matematis siswa dapat ditingkatkan seperti kemampuan pemecahan masalah (Megiana et al., 2018), (Sari et al., 2019), kemampuan koneksi dan komunikasi matematis (Puspita \& Saputri, 2020) dan lain sebagainya. Beberapa penelitian juga telah menunjukkan bahwa penggunaan software yang disertai metode dan model pembelajaran yang tepat dapat meningkatkan hasil belajar matematika siswa (Yunita, 2020). Geogebra dapat pula diaplikasikan untuk mempelajari topik selain geometri yaitu program linear (Idris, 2015).

Setelah kegiatan pengabdian, diharapkan siswa dapat berlatih secara mandiri dalam menyelesaikan soal-soal matematika khususnya topik geometri. Guru juga mendapatkan ide untuk menciptakan suasana belajar di kelas yang baru dan menyenangkan dengan peggunaan Geogebra versi android ini. Selaian itu guru juga dapat memberikan umpan balik secara langsung kepada siswa pada saat menyelesaikan soal-soal latihan. Output yang dihasilakan pula dari kegiatan pengabdian ini yaitu tim pengabdi membuat suatu buku panduan mengenai penggunaan aplikasi Geogebra versi Android.

\section{KESIMPULAN}

Penggunaan aplikasi Geogebra versi android memudahkan siswa untuk mempelajari konsep-konsep matematika khususnya topik geometri. Selain itu, waktu pengerjaan soal dengan menggunakan Geogebra versi android menjadi lebih cepat. Para siswa sangat termotivasi dan sangat antusias mempelajari topik Geometri dengan adanya aplikasi Geogebra versi android ini. Dengan adanya aplikasi Geogebra versi android ini menambah wawasan guru dalam merencanakan proses pembelajaran yang lebih inovatif.

\section{UCAPAN TERIMA KASIH}

Tim pengabdi mengucapkan banyak terima kasih kepada seluruh pihak yang ikut membantu melancarkan dan mensukseskan kegiatan pengabdian ini, terkhusus kepada Kepala sekolah M.Ts. Nurul Falah dan guru mata pelajaran matematika yang telah banyak membantu dan menerima gagasan/ide tim pengabdi, para siswa peserta kegiatan yang sudah meluangkan waktu diluar jam sekolah untuk hadir mengikuti rangkaian kegiatan. Lembaga Penelitian dan Pengabdian Masyarakat (LPPM) Universitas Timor juga sangat membantu dalam pemberian izin dan memberikan dukungan atas terselenggaranya kegiatan pengabdian ini.

\section{DAFTAR PUSTAKA}

Agung, S. (2016). Pemanfaatan aplikasi geogebra dalam pembelajaran matematika smp. Prosiding Seminar Nasional, 03, 312-322.

Annajmi. (2016). Peningkatan Kemampuan Pemahaman Konsep Matematik Siswa SMP Melalui Metode Penemuan Terbimbing Berbantuan Software Geogebra. MES (Journal of Mathematics Eduacation and Science), 2(1), 1-10.

Bernard, M., \& Senjayawati, E. (2019). Meningkatkan Kemampuan Koneksi Matematik Siswa SMP dengan Menggunakan Pendekatan Metaphorical Thinking Berbantuan 
Software Geogebra. Jurnal Penelitian Matematika Dan Pendidikan Matematika, 3(2), 79-87.

Chronika, A., Manalu, S., Jumiati, Y., \& Setiawan, W. (2019). Analisis minat belajar matematika siswa smp kelas viii pada materi persamaan garis lurus berbantu aplikasi geogebra. Jurnal On Education, 02(01), 63-69.

Fitriani, F., S., M. T., \& Bete, H. (2019). Pemanfaatan Software Geogebra Dalam Pembelajaran Matematika. Jurnal Pendidikan Dan Pengabdian Masyarakat, 2(4), 460-465. https://doi.org/10.19109/jpmrafa.v3i1.1441

Herlina, N., Fitriah, A., \& Setiawan, W. (2019). Peningkatan hasil belajar matematika pada materi bangun ruang sisi datar melalui aplikasi geogebra siswa smp di bandung barat. Jurnal On Education, 01(03), 471-477.

Idris, S. (2015). Peningkatan Hasil Belajar Program Linear melalui Strategi Pembelajaran Inkuiri dan Geogebra Siswa Kelas XII IPA1 SMA N 1 Tompobulu. Indonesian Digital Journal Og Mathematics and Education, 2(3), 144-153.

Kusuma, A. B., \& Eka, S. (2015). Peningkatan Kemampuan Representasi Matematis Mahasiswa Menggunakan Media Program Geogebra pada Mata Kuliah Geometri Ttransformasi. Khazanah Pendidikan, 2(1), 15-25. jurnalnasional.ump.ac.id

Megiana Pertiwi, C., Fitriani, T., \& Afrilianto, M. (2018). Relasi antara Kemampuan Pemecahan Masalah Matematik dan Keaktifan Belajar Matematik Siswa SMP yang Menggunakan Pendekatan Realistic Mathematic Education Berbantuan Geogebra. Jurnal Pembelajaran Matematika Inovatif, 1(4), 513-524.

Muflih, M., Hamzah, H., \& Puniawan, W. A. (2017). Penggunaan Smartphone Dan Interaksi Sosial Pada Remaja Di Sma Negeri I Kalasan Sleman Yogyakarta. Idea Nursing Journal, 8(1), 12-18.

Ningsih, F., Putra, A., \& Ulandari, N. (2019). Penerapan Pendekatan Saintifik Berbantuan Geogebra dalam Upaya Meningkatkan Pemahaman Konsep Matematis Siswa. AKSIOMA, 10(2), 180-194.

Puspita Sari, D., \& Saputri, L. (2020). Peningkatan Kemampuan Komunikasi Matematis Melalui Model Pembelajaran Probing Prompting dengan Media Geogebra Pada Siswa Kelas VIII SMP Negeri 2 Stabat. Math Education Nusantara, 3(1), 1-12.

Qurohman, M. T., Romadhon, S. A., \& Wulandari, R. (2018). Peningkatan Kompetensi Siswa dan Guru SMK Dinamika Kota Tegal tentang Pemanfaatan Program Komputasi Matematika Geogebra. ABDIMAS, 3, 1-4.

Ramadhani, R. (2016). Peningkatan Kemampuan Pemecahan Masalah Matematika Siswa SMA melalui Model Problem Based Learning Berbantuan Software Geogebra. INTEGRITAS, 2(1).

Sari, P. C., Eriani, N. D., Audina, T., \& Setiawan, W. (2019). Pengaruh pembelajaran berbantuan geogebra terhadap peningkatan kemampuan pemecahan masalah matematik siswa smp. Jurnal On Education, 01(03), 411-416.

Yunita, S. (2020). Meningkatkan Hasil Belajar Siswa pada Materi TRansformasi Melalui Media Geogebra Kelas IX di SMP N 2 Banjit Way Kanan. Attractive: Innovative Education Journal, 2(2). https://www.attractivejournal.com/index.php/aj/ 